\title{
DIASPORIC TOURISM IN WESTERN UKRAINE: PERSPECTIVES AND CHALLENGES
}

\author{
Andrea Corsale ${ }^{1}$, Olha Vuytsyk ${ }^{2}$ \\ ${ }^{1}$ University of Cagliari, \\ Via Is Mirrionis, 1, IT-09123 Cagliari, Italy \\ ${ }^{2}$ Ivan Franko National University of Lviv, \\ P. Doroshenko Str., 41, UA - 79000 Lviv, Ukraine
}

This study analyses the perspectives of roots tourism through the experiences of Western Ukrainian diaspora members visiting their places of origin and the views by tour operators specialised in roots tourism and public authorities dealing with tourism in the region, evaluating the actual or potential impact in terms of tourism development opportunities. The peculiar history of this territory makes it a distinct research target, with dynamics that are different from the rest of the country. The desire to turn Western Ukraine into a solid tourist destination and the aim of stimulating economic development in a region that is still struggling to re-emerge from its marginality are widespread and form a fertile basis for the growth of diaspora tourism as a solid asset.

The case of the Ukrainian diaspora and its relations with roots tourism is important because it holds partial yet significant similarities with many other diaspora histories and groups. The emotional links with the homeland are strong among the first generation migrants, while second and further generations of Ukrainian migrants show weaker personal connections with Ukraine, yet still show widespread interest in visiting the country of their ancestors.

Lights and shadows emerge from the diaspora tourists' experiences and perceptions. Specialised tour operators clearly see the enhancement of this form of tourism as an important business opportunity, while public authorities are not currently focusing on this segment, preferring general tourism promotion.

Key words: Diaspora, roots tourism, Western Ukraine, identity, development.

The term "diaspora" generally tends to include many kinds of population groups, such as migrants, political refugees, foreign workers, overseas communities, ethnic and religious minorities living out of their original homelands for different reasons [17, 22]. These people usually maintain cultural and psychological attachment to their places of origin, even after several generations $[1,12,24]$.

English terms such as "roots tourism" and "diasporic", "genealogical", "ancestry" or "nostalgic" tourism embrace this form of travel and underline its two main dimensions: identity and tourism. People are motivated to travel to places where they believe they have roots and from where their families are thought to have originated.

Topics related to roots tourism have been covered by scholars such as Basu [2], McCain and Ray [15], and Coles and Timothy [5]. According to Basu [2], the "return to the roots" is a real physical movement, as well as an act of belonging expressed through visits to ancestral heritage locations, and a more generalised collective project of connection to the homeland. McCain and Ray define roots tourists as "individuals who travel to engage in genealogical endeavours, to search for information or to simply feel connected to ancestors

C Corsale A., Vuytsyk O., 2015 
and ancestral roots". Similarly, Cole and Timothy consider roots tourism as a form of personal heritage tourism which involves people who possess emotional connections to the land of their ancestors.

This study contributes to the literature on roots tourism by exploring and discussing visits to the homeland made by members of the Ukrainian diaspora, and their descendants, living in Canada and the United States, after their emigration from the region of the present Western Ukraine, with its specific socio-economic features that turned it into a place of origin for important flows of migrants between the $19^{\text {th }}$ and the $20^{\text {th }}$ century. Specifically, this study analyses what induces those people to visit Ukraine, how they perceive and experience the places, and how tourism business and local authorities deal with this segment of the tourism market, in order to evaluate its current and potential impact within the tourism sector in Western Ukraine and the rest of the country.

No comprehensive studies on the perspectives of roots tourism have been done in Ukraine, yet. Although some issues of nostalgic tourism development have been discussed by several authors $[13,14,21,26]$, and the question of the complex identity of the Ukrainian diaspora has been analysed by Smith \& Jackson [23], Satzewich [20], Wolowyna [27], Isajiw [9]. The key issues related to the motivational behaviour of nostalgic tourists, their relationship with the Ukrainian cultural environment, as well as the aspects related to the organisation of related travel services and the opportunities for local development in Ukraine, have not been sufficiently explored, yet.

According to our findings, beyond the current geopolitical tensions and conflicts in the Eastern part of the country, with their heavy negative impact on tourism in the whole of the country, the Ukrainian diaspora needs focused, complex and well-grounded economic and cultural policies in order to preserve and strengthen significant relations between the current places of living and the regions of origin over longer terms and thus become a strong and recognised tourism segment.

\section{The Western Ukrainian diaspora}

This research is mainly aimed at investigating roots tourism-related experiences of the Ukrainian diaspora which originated from the western regions of Ukraine, as the emigration history of this part of the country has been particularly long and complex, thus creating large and heterogeneous communities abroad [23]. Divisions between socialists and nationalists, Catholic and Orthodox churches, new-wave immigrants and longer-settled members of the community have all at some point fractured the Ukrainian diaspora [20].

Massive emigration started affecting Western Ukraine at the end of the $19^{\text {th }}$ century. Due to the numerous socio-economic issues that affected Galicia and Bukovina, several organisations started to operate in order to help the different ethnic groups living in the region, particularly Ukrainians, Poles, Jews and Germans, to move overseas.

The Austrian government authorised the opening of numerous branches of nautical companies whose agents promoted the emigration option among local people. As a result of the activities of the government and nautical companies, hundreds of thousands of Ukrainians, Poles, Jews and Germans migrated mainly to North and South America. Following World War II and the subsequent border changes, the ethnic composition of Western Ukraine saw drastic modifications. Nowadays, Ukrainians form the vast majority of the population in all the counties (oblasts), while Polish, Jewish, German, Romanian, Hungarian and Russian communities form dwindling minorities. 
The emigration of ethnic Ukrainians from Western Ukraine occurred through four main waves $[8,20,26]$. The first one was primarily caused by economic reasons and lasted from the beginning of the 1870s until the First World War; the second one was caused by both economic and political factors and coincided with the period between the two world wars (1918-1939), while the third wave was mainly political and started during World War II lasting into the immediate postwar period. A fourth wave, mainly characterised by labour emigration, started after the independence of Ukraine in 1991 and is still going on. During the Soviet time, forced population mixing within the Union created large Ukrainian communities currently living in Russia, Kazakhstan, Uzbekistan, Kyrgyzstan, Latvia and other former Soviet republics.

The main destinations of the first three emigration waves of ethnic Ukrainians were Canada and the United States, with smaller flows heading towards South America, mainly Brazil, Argentina and Paraguay, Western Europe and Australia, while the most recent one is mainly directed towards Western Europe [10, 11]. According to different estimates, the number of ethnic Ukrainians living abroad ranges between 12 and 20 million people [28, 31].

The Ukrainian diaspora in Canada

The Ukrainian diaspora community living in Canada is the largest in the Western world. According to the 2011 census, 1,251,070 people in Canada declared Ukrainian ancestry out of a total of $34,342,780$ people, up from $1,209,085$ in 2006 , although their share of the total population dropped from $3.9 \%$ in 2006 to $3.6 \%$ in 2011. They currently form $14.7 \%$ of the population in Manitoba, $13.6 \%$ in Saskatchewan and $10.2 \%$ in Alberta. According to the same census, 111,540 of them speak Ukrainian as mother tongue, down from 134,500 in 2006. In 2011, 2,455 people from Ukraine migrated to Canada out of 248,748 immigrants $(1.0 \%)$ [32]. Although the Prairie Provinces still maintain large communities, Ukrainians have been spreading across the country in search of better economic conditions and better quality of life. The urbanisation trend has been pronounced for a number of decades, and now $75 \%$ of the Ukrainian population of Canada lives in cities, similarly to the general population of the country [33].

The Ukrainian diaspora in the United States of America

The number of Ukrainian descendants in the United States, according to the census of 2010 , comprised 931,297 people ( $0.3 \%$ of the total population), up from 740,723 in 1990 [30], although some American demographers believe that the actual representation of Ukrainian ethnos in the USA is more than 1.5 million people (Institute of the Ukrainian Diaspora Studies). According to the 2010 census, $15.3 \%$ of Ukrainians declared speaking the Ukrainian language at home. The States with the largest numbers of Ukrainian descendants are New York $(129,603$ people, $13.9 \%$ of the total Ukrainian population in the USA), Pennsylvania (112,078 people, $12.0 \%)$ and California $(92,943$ people, $10.0 \%)$.

Methodology

In order to investigate diasporic tourism related to Ukraine, with its complex features and implications, a multidisciplinary approach was chosen, including research on the specific historical background and economic context. A mix of qualitative and quantitative methods was adopted. The authors considered both the statistics related to the potential and the effective business associated with tourism, particularly diasporic tourism, in Ukraine (using quantitative methods), and the information directly obtained from selected stakeholders and tourists in terms of personal histories, identities, experiences, expectations and views (qualitative methods). In particular, concerning the qualitative part, data collection 
incorporated the three main sources of information recognised in qualitative research: consultation of secondary sources, observations and questionnaires/interviews [16, 19].

The direct investigation was conducted in two stages:

- first, the potential or actual consumers of the Ukrainian nostalgic tourism product were surveyed, i.e., a sample of tourists who have already visited Ukraine and have Western Ukrainian origins, or are just planning to travel to their historical homeland;

- the next stage of the project was surveying tour operators specialised in the organisation of nostalgic tours to Ukraine;

The objectives of the survey among current/potential consumers of the nostalgic tourism product were studying the motivations for emigration from Ukraine, the relations with the Ukrainian cultural environment, as well as the aspects of nostalgic tours organisation to Western Ukraine.

In the first stage, current or potential nostalgic tourists were approached through existing online forums and communities linking the Ukrainian diaspora members in Canada and the US during the months of April-September 2013. The aims of the academic research were clearly presented, calling for volunteers willing to tell about their sense of belonging and identity, their travel experiences or plans. Only questionnaires from self-declared ethnic Ukrainian people who had links with Western Ukraine were analysed, regardless of their religious identification. The identification with a "first generation" and a second or subsequent generation of Ukrainian migrants was left to the respondents. The survey was focused on communities living in North America, rather than Western Europe, in order to better show links between diaspora and homeland over longer time and distances. A total of 45 people participated in the survey. The questionnaire included a series of questions, mostly allowing open answers, aimed at highlighting their connections with Western Ukraine, their expectations and reactions related to travelling in Ukraine, and their suggestions for tourism services improvement and for tourism development in the region and in this specific segment.

In the second stage, tour operators dealing with Ukrainian nostalgic tourism, both local and foreign, were approached through the internet during the months of September and October 2013. In this case, as well, the aims of the research were openly presented, calling for voluntary contributions about their experiences in this tourism segment and their views on obstacles and potential. The questionnaire included a limited number of questions, mostly allowing open answers. A total of eight tour operators joined the project; five of them are based in the United States, Canada and Australia, while three of them are based in Ukraine.

\section{Context and Results}

Diaspora tourism development might become crucial for Ukraine's economy recovery. Since introducing Ukraine as a tourist destination to the international tourist market is still difficult, diaspora populations can play an important role as "first movers" in opening new opportunities in the international market. Emigrants or their descendants can also spread the word about the attractions in Ukraine, being sources of valuable word-of-mouth advertising. This may result in attracting non-diaspora customers to Ukraine.

Root tourism might thus be a significant tourism market, which is now undervalued, as stressed by several interviewees.

"In our Canadian family, we have grown to approximately 390 people. Until now I have been the only one to visit Ukraine. I'm sure there are many families like ours. With political and 
continuing economic changes in Ukraine I think root tourism is economic opportunity there", Betty, 70 years old, Canada, third generation."

Out of the 45 collected questionnaires, males represent $61 \%$ of the respondents and females $39 \%$. Most of the respondents (82\%) were born in the 1930s, 1940s and 1950s. The research revealed that $88 \%$ of the respondents belong to the second and third generations of migrants and only $12 \%$ - to the first generation.

Following the growth of inbound tourism, many Ukrainian companies that used to specialise in outbound tourism, such as beach holidays in Turkey, Egypt and Croatia, tend to diversify their activities and create new company departments in order to attract foreign tourists to Ukraine.

The results of the research focus on eliciting and analysing the importance of cultural, social, religious attachments of the Ukrainian diaspora as well as their reflections on visits to Ukraine in the context of tourism planning and development. The following implications and policy recommendations, relevant to organisations interested in diaspora tourism development in Western Ukraine (central and local governments, private businesses, DMO, etc.), were observed and made as a result of the research:

1) Fostering the interconnections between Ukrainian cultural and religious organisations abroad and in Ukraine;

2) Ensuring security and safety for international tourists visiting the country;

3) Identification and research of potential nostalgic tourists;

4) Promotion of genealogy tourism;

5) Marketing and branding of Ukraine as a destination for root tourism;

6) Development of the rural areas.

Cultural and religious interconnections

Cultural and religious aspects of Ukrainian identity and their importance for diaspora members should be kept in mind when planning the incoming tourism development and targeting the root tourists.

Public authorities and NGOs may help to promote diaspora tourism through fostering the interconnections between Ukrainian cultural/religious organisations in Ukraine and abroad. This can be only achieved through a tight cooperation between the public and private sector, for example through the promotion of students' exchange programmes, summer language camps for Ukrainian descendants, festivals, etc.

Indeed, practices of education, religion and language are acknowledged determinants of diaspora's identity [9].

According to Isajiw [9], assessing generational Ukrainian identity retention among Ukrainians in Canada, more than $80 \%$ of second and third generation migrants still eat Ukrainian traditional food on holidays and possess Ukrainian artistic articles. In the second generation, $60 \%$ to $80 \%$ know the Ukrainian language as their mother tongue, practice Ukrainian ethnic customs and feel an obligation to teach their language to their children, while, in the third generation, only $30 \%$ do [9].

The results of the present survey confirm this trend. The majority of respondents show high interest in Ukrainian culture. Most of them are tightly connected with several kinds of Ukrainian cultural organisations abroad. Even though some know very little about Ukraine and its culture, they express interest in learning about it.

\footnotetext{
* Pseudonyms are used throughout this paper conforming to the norms of social science ethics.
} 
Ukrainian language

The Ukrainian identity is often associated with the ability to speak the Ukrainian language. In fact, though, there is a decline in Ukrainian language fluency among the second and subsequent generations of migrants $[9,20]$.

According to the census of 2010, in the USA, $15.3 \%$ of Ukrainians still speak the Ukrainian language at home. In Canada, the last census, held in 2011, registered $8.9 \%$ of Ukrainians who indicated the Ukrainian language as the language spoken at home.

Among the survey participants, $65.5 \%$ of respondents answered that they cannot speak Ukrainian, while $34.5 \%$ can still speak it (see figure). Some respondents stress that Ukrainian was their first language and they could not speak English until they went to school when they switched languages.

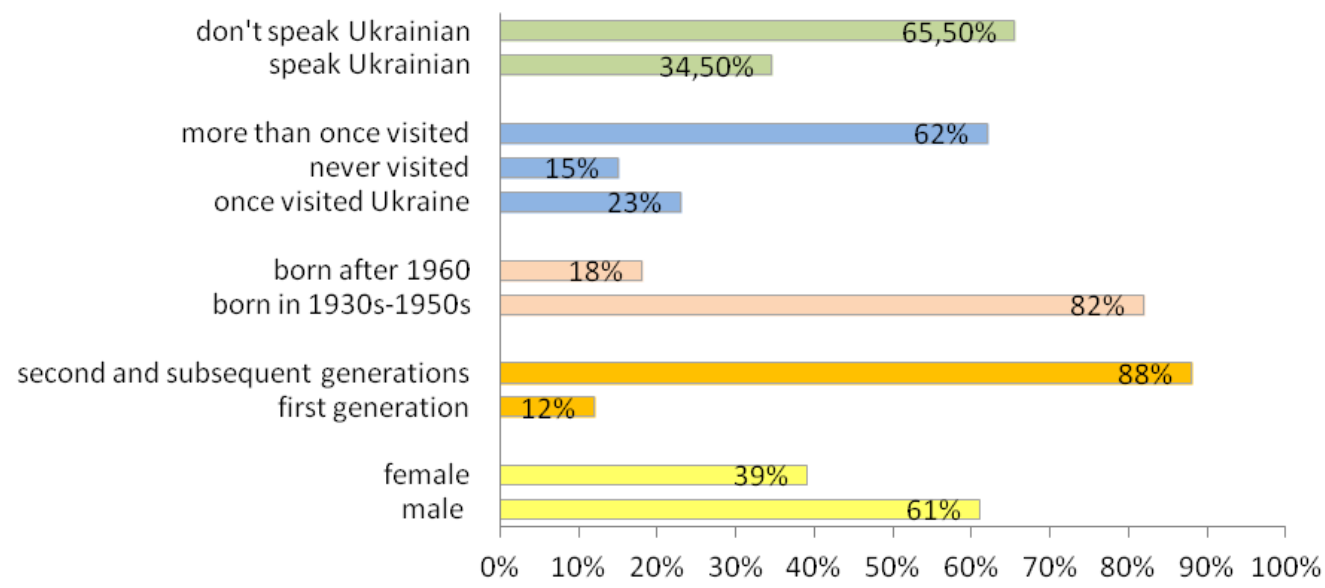

Some characteristics of the research participants, share \%

"I did speak Ukrainian as a child before I learned to speak English. When I entered primary school I lost that ability. I do, however, still understand some spoken Ukrainian”, Don, 76 years old, Canada, third generation.

Since Ukrainians who emigrated to the USA or Canada settled in rather uninhabited rural regions, there were no options for kids to attend kindergartens. They usually stayed home with their parents and grandparents who spoke only Ukrainian.

"The way that the settlements were settled - each family was given 160 acres of land to farm. Therefore there were 4 families on a section of land which is 640 acres. The families were fairly large - 4-14 parents and children in a family. Therefore they built their own schools and churches in close proximity as the mode of transportation was horses or walking", Lindsay, 68 years old, Canada third generation.

"I can speak very poor Ukrainian but I know by heart kolyadky [Ukrainian Christmas carols]. When I was in Hawaii some time ago, everyone of the group was asked to sing their traditional Christmas songs - I've sung Ukrainian kolyadka", Roy, 66 years old, Canada, third generation.

In spite of this decline, diaspora members often attend classes in Ukrainian language and culture to revive their roots at later stages.

Orthodox and Catholic churches and various cultural organisations created or helped to create a combination of community-sponsored supplementary schools and accredited 
language schools within the public school systems. Classes in Ukrainian language, history and culture in supplementary schools are held outside of normal school hours, usually on Saturdays. Satzewich [20] stresses that the second and subsequent generations of Ukrainians living in North America have a Ukrainian identity and feel that Ukrainian heritage is important to them even when they may not be fluent in the Ukrainian language.

\section{Ukrainian traditions}

Language is not the only relevant Ukrainian ethnic identity aspect. Other important elements are cooking traditional Ukrainian food, possession of artistic Ukrainian objects and traditional celebrations of religious holidays, such as Christmas and Easter. Traditional dances, songs and clothes, such as embroidered shirts [vyshyvanka], together with typical crafts (Easter eggs decoration, weaving, etc.), also contribute to a strong sense of belonging and national identity.

"Ukrainian traditions were observed at home during Ukrainian weddings, Christmas, Easter, funerals and other holidays", Dennis, 60 years old, Canada, third generation.

"My mother was renowned for her Ukrainian Easter eggs. It was her legacy to us", Jason, 67 years old, USA, third generation.

One of the respondents says that they never worked on Sundays, according to religious tradition observed among Ukrainians. However, as time passes, these traditions are not as closely kept by the second and subsequent generations of Ukrainians.

"My father passed in 2000 and till he passed he would not mow the lawn or do any work and frowned on us doing anything even if we were out for the weekend and wanted to help him", Michael, 74 years old, Canada, third generation.

As observed through the survey, a very important form of social connection with the homeland occurs through membership in different kinds of Ukrainian cultural NGOs, such as Ukrainian Village Society, SUM (Ukrainian Youth Organization), Plast (Ukrainian scout organisation), Ukrainian Canadian Congress, dance ensembles, charitable societies, etc.

Ukrainian dancing schools and choirs successfully function in the areas where Ukrainian communities live. Some families with virtually no other connections to the organised Ukrainian community still often send their children to learn the hopak, kolomyika and other Ukrainian dances [20].

Many respondents (62\%) report frequently attending events connected to Ukrainian culture, such as folk dance performances and celebrations of important religious holidays, particularly Christmas, Malanka (Old New Year, celebrated on January $14^{\text {th }}$ ), Easter, etc. Moreover, in areas where many Ukrainians live, Ukrainian festivals are extremely popular, such as Toronto Ukrainian Festival (Ontario, Canada), Annual Baltimore Ukrainian Festival (Maryland, USA), Ukrainian Day in Ukrainian Cultural Heritage Village (Alberta, Canada), Vegreville Pysanka (Easter Egg) Festival (Alberta, Canada), Chicago Ukrainian Festival (Illinois, USA), Saint Josaphat's Ukrainian Festival in Rochester (New York, USA) etc.

Some of the interviewees are deeply involved in the preservation and popularisation of Ukrainian culture.

"I studied Ukrainian language, history, grammar, culture in Ukrainian school every Saturday from kindergarten till senior year in high school. I took up Ukrainian dancing at age 7, performed at various festivals, and then I founded a Ukrainian school of folk dance, which today has over 225 students", Roxana, 55 years old, USA, second generation. 
Food also seems to be a means of actively maintaining an emotional link with the homeland as both a physical landscape and cultural home. Food has a place both in everyday life and in rituals and customs that can inspire an emotive reflection of self and community [4].

The analysis of the itineraries offered by the tour operators specialised in root tourism supports these reflections. Most of them include traditional Ukrainian restaurants as dining places for tourists. Thus, cooking classes of Ukrainian traditional food could add further value to their experience.

Practicing religion

One of the most distinctive features of Ukrainian communities living abroad is their belonging to either the Ukrainian Orthodox or the Ukrainian Greek-Catholic church. Religion seems to be another important aspect of Ukrainian identity. Practising faith, including visits to church on Sundays, religious calendar observances, children baptising in Ukrainian church, church marriage, regular celebratory events, constitutes an important part of the daily life of the Ukrainian community.

"There is no cremation at our Church. Ukrainian Holidays were sacred and observed by all. Sundays were observed religiously”, Nestor, 67 years old, Canada, third generation.

"My grandparents were active in the Ukrainian community of Chicago. My parents have always lived in Chicago, but went to Ukrainian school, sang in choirs, belonged to instrumental groups, and are still very active in the Ukrainian Orthodox Church in Chicago", Elizabeth, 27 years old, USA, third generation.

During their tours, the surveyed diaspora tourists willingly visit churches, monasteries and other sacral places.

"When travelling to Ukraine, I felt very connected to many of the churches and religious places visited. St. Sophia is the mother of the Ukrainian church and I belong to St. Sophia Ukrainian Orthodox Church here in Chicago. It felt like a pilgrimage", Iryna, 35 years old, USA, third generation.

Many tours to Ukraine are organised with the assistance of Ukrainian Greek Catholic or Orthodox churches. Information about the tours is also spread among the community members in church newspapers. Church, in this case, can help to share information about visits to the homeland and to connect producers with diaspora markets. Tour advertisements in church newspapers are also used as a promotion channel by $25 \%$ of the surveyed tour operators.

Ensuring security and safety for international tourists visiting Ukraine

Safety and security are among the most important aspects of incoming tourism development in Ukraine. In 2014 international tourist flows to the country significantly dropped because of the ongoing armed conflict in the eastern regions. But even before that, in the period when surveying was conducted, people had some fears about their security when visiting Ukraine.

"Before my first visit to Ukraine (in 1996) I was told not to take any jewellery with me to Ukraine. Now I can say it's safe there”, Mary, 67 years old, Canada, second generation.

"Many people who are older have never visited Ukraine because they are afraid or don't know what to expect, but want to go", Kate, 27 years old, USA, third generation. 
The reasons which restrain people from travelling to the country are not linked to real danger or insecurity but to the image of Ukraine as a dangerous and tourist-unfriendly country. This image strengthened during the 1990s when, after the collapse of the Soviet Union and the Iron Curtain, many thousands of Ukrainians from the diaspora could visit the country for the first time. During that period of time, several fraudulent travel agencies deceived their clients and crime resurgence made the country not safe for standard Western visitors.

In 2014 and 2015, diaspora travellers, as well as other tourists, were particularly sensitive to the threats posed by the war in Donbas. According to governmental data, international tourist flows in 2014 decreased by $50 \%$ compared to 2013. Even though the conflict involves approximately $7 \%$ of the Ukrainian territory, in the east of the country, and the western regions are comparatively safe, the negative image of the war-affected area tends to affect the whole country.

Many examples of tourist destinations around the world (e.g. Israel, Sri Lanka, Georgia) show that a conflict in one part of the country does not necessarily prevent tourism development in other parts. Thus, public authorities responsible for tourism development should emphasize the safety of the greater part of the country and the distances between the war zone and other tourist destinations within the same country (e.g. the distance from Donetsk to Lviv is $1300 \mathrm{~km}$, which is comparable to the distance from Lviv to Venice), promoting awareness among potential tourists and fostering tourism development in the areas which are not affected by the armed conflict.

\section{Identification and research of the potential nostalgic tourists}

The research of the potential root tourists, their demographic, social and cultural characteristics, measuring the scope and patterns of diaspora activities, may help to identify and target their needs and, with a proper marketing campaign, encourage them to visit their historic homeland [3, 6, 25].

As it was stressed by several researchers $[1,4,7]$, the feeling of nostalgia for homeland and people, and the desire to seek and strengthen cultural or social identities, are strong factors compelling trips back home. It is generally recognised that second, third and subsequent generations of migrants are more interested in cultural, historical heritage - both tangible and intangible - since family connections are much weaker than among the recent migrants $[4,9]$.

Visits to Ukraine are highly popular among the survey respondents, $62 \%$ of them having visited Ukraine more than once. Only $15 \%$ of the respondents have never visited the region (see figure).

A high percentage of respondents $(78.9 \%)$ declares to be willing to visit Ukraine again, which shows that the will to maintain ties between the diaspora and the historic homeland is quite strong. None of the respondents answering the question about their desire to revisit Ukraine in the future says "no"; $21.1 \%$ answers "do not know".

The answers of the tour operators are somewhat different: most of them indicate that only about $15-25 \%$ of customers who travelled to Ukraine for the first time intend to come back again in the near future.

The majority of respondents $(52.4 \%$ ) first visited Ukraine in their 60 's, while $23.8 \%$ did so in their late 40's. The average age for the first visit was 49.1 years. All surveyed tour operators also noted that retired and middle-aged visitors are most interested in making trips to Ukraine. 
Most respondents travelled with spouses, children, parents; some travelled with dance ensembles or choirs. The majority of them stayed in hotels $(85.7 \%)$, although some were hosted by relatives or stayed in apartments. The average length of stay was about 12-14 days.

The survey among tour operators confirmed that the main motivations for Ukrainian descendants making trips to Western Ukraine are, above all, visiting relatives and friends as well as exploring their family history. The second motivation is discovering the country's historical and cultural heritage, also beyond the borders of Western Ukraine.

Although family history and visiting friends and relatives (if any) are very important, the respondents also show high interest in discovering cultural heritage $(66.7 \%)$ and natural environment $(20.8 \%)$, also beyond the Western part of the country.

It should be noted that the majority of foreign tourists prefer organised tours in terms of trip organisation. Amateur tours in Ukraine can be particularly challenging for North American tourists because of language barriers, lack of tourism information, weak transportation and bad road conditions. Travel agencies and tour operators specialising in this segment are likely to have good chances of business growth, as $74 \%$ of the interviewees said they would need organisational support to travel in Ukraine.

The average spending of surveyed nostalgic tourists during their visit to Ukraine was about 150-200 USD per day, which confirms available statistical data, as, in 2012, the average spending of a foreign tourist was 208 USD per day [29]. Considering the longer stay in Ukraine (12-14 days rather than 3-4 for cultural or conventional tourists), the expenditures are much higher than general cultural tourists.

Promotion of genealogy tourism

The desire to learn more about family history is among the major reasons for visiting Ukraine. This is also confirmed by the answers of the respondents where they mention that they are interested in genealogy $(84 \%)$ and have already done $(64 \%)$ or intend to do $(16 \%)$ some form of genealogical research.

In order to help the potential tourists with the genealogy search, Ukrainian government may encourage genealogy tourism by cataloguing and facilitating access to birth, death, marriage, and baptism records. At the moment, for a non-Ukrainian speaking person, it is rather complicated to contact and receive information from public archives.

"It would be easier to go to the area where your relatives came from and someone could help you hopefully find living relatives or your roots", Nancy, 67 years old, Canada, third generation.

There are a number of successful international initiatives aimed at helping diaspora members to track down documentation and locate graves. Among these examples, the "Discover Ireland" Website provides relevant information that can be gathered before making a trip (e.g., the ancestor's name, date of birth, parish of origin etc.) [18].

Marketing and branding of Ukraine as a destination for root tourism

Due to the poor marketing campaigns, and lack of public efforts to specifically support Ukrainian diaspora members in visiting the land of their ancestors, Ukraine has persistent difficulties in becoming a strong root tourism destination.

It would be important for the Ukrainian tourism industry to develop and promote a national brand, and create a competitive tourist identity, actively marketing itself in the international tourist market. Direct media and social media marketing should be used to form an image of Ukraine as a tourist-friendly and interesting destination. 
In order to get information on Ukraine before their visit, the survey respondents consulted friends and relatives $(52.4 \%)$, the Internet $(47.6 \%)$, travel agents $(23.8 \%)$ and travel books $(19.0 \%)$.

The surveyed tour operators in the USA, Canada and Australia generally promote their tours amongst potential customers by advertising in newspapers for local Ukrainian communities $(100 \%)$, church newspapers $(25 \%)$ and by means of radio commercials $(25 \%)$. Only one of the surveyed tour operators promotes tours to Ukraine through the company website and none of them through social media, which shows low awareness of their significant potential for the promotion of the offered packages.

Some marketing attempts were made by the governmental Agency for Tourism and Resorts, but the policy was discontinued and fragmentary. At the moment, this agency is inactive and it is unclear who is in charge of the tourism policy in Ukraine. Many efforts are being made by governmental and self-governmental bodies at the regional or local level. Some Ukrainian tourist cities and towns are successfully promoting themselves separately from the country as a whole (Lviv, Odessa, Kyiv, Kamianets-Podilskyy, etc.). In order to facilitate diaspora tourism, it is important to help producers connect with diaspora markets. Many countries have their tourist offices at the consulates and embassies in the target markets (for instance, the Polish National Tourist Office has branches in 14 countries around the world). For Ukraine, it would be reasonable to open such offices in USA, Canada, Brazil and Argentina, providing relevant information on entry requirements, visa applications, travel information, etc. For example, in order to answer logistical questions about travel by Mexican emigrants, Mexico's Programa Paisano runs a dedicated website, staffs a 24-hour phone line and prints more than a million booklets each year containing information about entry and visit, imports and exports of personal goods, etc. [18].

There is an urgent need to create informative and up to date website providing information on visits to Ukraine, tourist highlights, visa regime, customs regulations, etc.

There is currently no official website of Ukraine as a tourist destination and, as already observed, very little marketing actions are done in order to specifically attract nostalgic tourists, besides the initiatives taken in Lviv and other cities.

Assets for the development of the rural areas

As already noted, diaspora travellers are more likely to expand the geographic boundaries of classic tourist trails visiting remote and lesser-known areas. Moreover, diaspora tourism is not necessarily as seasonal as international tourism, and provides opportunities for employment and use of infrastructure in off-peak periods. This helps to involve local communities into tourism business, creating job places for local people, supporting smaller entrepreneurs, creating artisanal family-owned enterprises, etc.

Developing tourism venues in such areas may have even greater multiplying effects on the local economy. In Ukraine, several regions, particularly mountainous and rural areas far from the big cities, still have a weak tourism industry and their communities face many social and economic problems - high levels of unemployment, poor infrastructure, lack of adequate roads, sewerage, water and gas supply systems, etc.

Diasporic tourism provides an important opportunity to balance and spread the benefits of tourism spending to less developed areas. Indeed, diaspora tourists are more likely to buy locally-produced commodities and eat local food, thus contributing to the development of smaller business and supporting local vendors [18] 
In order to develop these rural areas, according to the survey respondents, the following actions are recommended:

- Encourage investments in smaller rather than big local ventures, since small ventures are usually locally-owned and tend to invest their profits in the surrounding community;

- Increasing awareness of the role of diaspora in tourism development;

- Incentives to invest in tourist infrastructure - e.g. roads, information centres, hotels;

- Encouraging better local governance;

- Development of the policy and regulations that involve the local community;

- $\quad$ Education and training for the local entrepreneurs.

The majority of respondents stress the potential of Ukraine as a tourist destination. The most frequently mentioned positive aspects about their visits to Ukraine are good food, beautiful countryside, cultural heritage, churches, friendly people, diverse historic sights, etc.

At the same time, according to the results of the research, the interviewees found some particularly widespread weaknesses: roads in bad conditions, lack of public washrooms, few dining options in rural areas, lack of elevators in hotels, poor knowledge of foreign languages, lack of professionalism of hotel and restaurant staff.

Roots tourism is emerging as a solid asset for tourism and general local development in many countries with recent or older emigration histories. The most successful cases of roots tourism development seem to imply clear and focused policies aimed at reinforcing the ties between the country of origin and the diaspora. Stronger involvement of diasporas in the protection of cultural and natural heritage, social aid, economic investments and marketing for homeland export products are important side opportunities which can arise from a strong roots tourism sector.

This study focused on Western Ukrainian diaspora communities living in Canada and the United States, where they count over 2 million self-identified members.

Even though diasporic tourism still presents evident weaknesses and is still far from being a major economic sector for the country, in the nearest future it has all perspectives to become an efficient economic tool for local development, especially in rural areas. Surveyed nostalgic tourists visit rural areas more frequently than other tourists, they stay in Ukraine for a longer period of time, tend to spend more money, can generate business contacts with richer countries, and promote and preserve Ukrainian culture as an important link with the ancestors.

Marketing programmes and actions by the Ukrainian Government and by county and municipal authorities, in order to develop roots tourism in the country, have been weak and episodic, so far, and no specific policies have been adopted. The fading identities already recorded among second and subsequent generation diaspora members prove that this kind of promotion ought to be adopted in the nearest future. Forms of partnership with the United States and Canada, as well as the European Union countries, could strengthen marketing policies and the creation or opening of archives, registers and cadastral maps could provide further important tools. Economic and cultural policies could be introduced in order to turn diasporas into resources for local development. For such policies to be well grounded, further investigation on residents' attitudes towards hosting roots tourism would be very useful, as well as exploration on their willingness to preserve the heritage of diasporic groups, particularly in areas characterized by deep social, economic, political, cultural and 
demographic changes which occurred after the migration time. Working for the preservation of local and dispersed tangible and intangible heritage, strengthening the inter- and intragenerational ties within specific cultural communities and elaborating development projects that may be able to translate these potentials into opportunities for effective sustainable development should become strategic aims.

Five key challenges for further diasporic tourism development in Ukraine arise from this research, through suggestions provided by surveyed tourists and tour operators and comparisons with best practices from other countries:

- the need for collaboration between local authorities and travel operators in order to promote this type of tourism, both in the Western and Eastern parts of Ukraine, aiming at increasing the number of people of Ukrainian origin visiting their historic homeland;

- the need for tourist services improvements, such as the creation of proper informational infrastructure for foreign tourists arriving in Ukraine, informative web platforms, road signs and informational boards about the local tourist attractions in English and other languages besides Ukrainian and Russian, etc;

- the creation and promotion of cross-border tourist routes including Western Ukraine and neighbouring Central-Eastern European countries (Poland, Hungary, Slovakia, Romania), which would help to strengthen the competitive position of Ukraine and its tourist products at the global tourist market;

- the necessity to diversify the programs of tours and tourist activities traditionally offered by Ukrainian and foreign travel companies specialised on tours to Ukraine. Many tourists expect more than just visiting churches, monuments and museums and also want to participate in traditional Ukrainian festivities, weddings, Christmas and Easter rites, cooking or music classes, etc.

- the need for effective marketing campaigns improving the image of Ukraine abroad.

In conclusion, the motivations and experiences of Western Ukrainian diaspora visiting the historic homeland could be described as positive. The interest in roots tourism for Ukrainian descendants clearly emerges through the surveys. The economic opportunities related to this kind of tourism, which can also support sustainable cultural and rural tourism, are relevant yet still underdeveloped. Tour operators are aware of business potential and have started exploring this market segment, while public authorities are still trying to promote the development of tourism in general, without focusing on the diaspora.

\section{REFERENCES}

1. Baldassar, L. (2001). Visits home: Migration experiences between Italy and Australia. Melbourne, Australia: Melbourne University Press.

2. Basu, P. (2005). Roots-tourism as return movement: Semantics and the Scottish diaspora. In Harper M. (Ed.), Emigrant homecomings: The return movement of emigrants (pp. 131-150). Manchester, UK: Manchester University Press.

3. Basu, P. (2007). Highland homecomings: Genealogy and heritage tourism in the Scottish diaspora. Abingdon, UK: Routledge.

4. Brown, J. (2011). Expressions of diasporic belonging: The divergent emotional geographies of Britain's Polish communities. Emotion, Space and Society, 4, 229-237.

5. Coles, T., \& Timothy, D. J. (Eds.). (2004). Tourism, diasporas and space. London, UK: Routledge. 
6. Duval, D. T. (2003). When hosts become guests: Return visits and diasporic identities in a Commonwealth Eastern Caribbean community. Current Issues in Tourism, 6(4), 267-308.

7. Hirsch, M., \& Spitzer, L. (2002). We would not have come without you: Generations of nostalgia. American Imago, 59(3), 253-276.

8. Hodovanska, O. (2011). The Newest Ukrainian Diaspora: Labour migrants in Italy, Spain and Portugal [Новітня українська діаспора: трудові мігранти в Італії, Іспанії та Португаліi]. Lviv: National Academy of Sciences of Ukraine (in Ukrainian).

9. Isajiw, W. (2010). The Ukrainian Diaspora. In The Call of the Homeland: Diaspora Nationalisms, Past and Present, 289-344.

10. Kacharaba, S. (1995). Ukrainian emigration. Emigration movement from Eastern Galicia and Northern Bukovyna in 1890-1914 [Українська еміграція. Еміграційний рух зі Східної Галичини та Північної Буковини в 1890-1914]. Lviv, Ukraine: Ivan Franko National University of Lviv (in Ukrainian).

11. Kacharaba, S. (2003). Emigration from Western Ukraine, 1919-1939 [Еміграція 3 західної України, 1919-1939]. Lviv, Ukraine: Ivan Franko National University of Lviv (in Ukrainian).

12. King, R. (2010). Geography and diasporas. In Iorio, M., \& Sistu, G. (Eds.), Dove finisce il mare (pp. 195-212). Italy: Sandhi.

13. Kuzyk, S. (2011). Tourism Geography [Географія туризму]. Kyiv, Ukraine: Znannya (in Ukrainian).

14. Lozynskyy, R., Kuchynska, I., \& Dorosh, Y. (2013). Geography of the resources for the nostalgic tourism development in Zhovkva district of Lviv region [Географія ресурсів ностальгійного туризму Жовківського району Львівської області], available at: http://lib.pu.if.ua/file/press/karpat-kraj-2013-1.pdf (in Ukrainian).

15. McCain, G., \& Ray, N. M. (2003). Legacy tourism: the search for personal meaning in heritage travel. Tourism Management, 24(6), 713-717.

16. Merriam, S. B. (Ed.). (2002). Qualitative Research in Practice. San Francisco, CA: Jossey-Bass.

17. Mitchell, K. (1997). Different diasporas and the type of hybridity. Environmental and Planning D: Society and Space, 15, 533-553.

18. Newland, K., \& Taylor, C. (2010). Heritage Tourism and Nostalgia Trade: A Diaspora Niche in the Development Landscape. Washington DC: Migration Policy Institute.

19. Patton, M. Q. (2002). Qualitative research \& evaluation methods. Thousand Oaks, CA: Sage Publications.

20. Satzewich, V. (2002). The Ukrainian Diaspora. London: Routledge.

21. Shandor, F., \& Klyap, M. (2013). Contemporary types of tourism [Сучасні різновиди туризму]. Kyiv, Ukraine: Znannya (in Ukrainian).

22. Shuval, J. T. (2000). Diaspora migration: Definitional ambiguities and a theoretical paradigm. International Migration, 38(5), 41-57.

23. Smith, G., \& Jackson, P. (1999). Narrating the nation: The 'imagined community' of Ukrainians in Bradford. Journal of Historical Geography, 25(3), 367-387.

24. Stephenson, M. L. (2002). Travelling to the ancestral homelands: The aspirations and experiences of a UK Caribbean community. Current Issues in Tourism, 5(5), 378-425.

25. Timothy, D. J., \& Guelke, J. K. (Eds.). (2008). Geography and genealogy: Locating personal pasts. Aldershot, UK: Ashgate. 
26. Zubyk, А. (2013). Diasporic tourism as an innovative type of tourism [Діаспорний туризм як інноваційний вид туризму]. Lviv, Ukraine: Ivan Franko National University of Lviv, 195-199.

27. Wolowyna, O. (2009). Geographical Dispersion of Ukrainians in the U.S.: 1990-2006. The Ukrainian Weekly, 43.

Websites (October 2015)

28. http://ukrainianworldcongress.org/ (Ukrainian World Congress)

29. http://ukrstat.gov.ua/ (State Statistics Service of Ukraine)

30. http://www.census.gov/ (United States Census Bureau)

31. http://www.oa.edu.ua/en/institutes/en_diaspora (Institute for Ukrainian Diaspora Studies)

32. http://www.statcan.gc.ca/ (Statistics Canada)

33. http://www.ualberta.ca/CIUS/ (Canadian Institute of Ukrainian Studies)

Стаття: надійшла до редакиії 30.10.2015 доопрацьована 08.11.2015 прийнята до друку 03.12.2015

\title{
ДІАСПОРНИЙ ТУРИЗМ В ЗАХІДНІЙ УКРАЇНІ: ПЕРСПЕКТИВИ ТА ВИКЛИКИ
}

\author{
Андреа Корсале ${ }^{1}$, Ольга Вуйцик ${ }^{2}$ \\ ${ }^{1}$ Університет Кальярі, \\ вул. Із Мірріоніз , 1, 09123, Кальярі, Італія \\ 2 Львівський національний університет імені Івана Франка, \\ вул. П. Дороченка, 41, 79000, м. Львів, Украӥна
}

У цьому дослідженні проаналізовано перспективи діаспорного туризму крізь призму досвіду представників діаспори із західної України, які відвідують свою історичну батьківщину. Систематизовано погляди туроператорів з України, США та Канади, що спеціалізуються на діаспорному туризмі.

Історичний розвиток західної України робить іiі особливим об’єктом дослідження. Наміри перетворити Західну Україну в привабливу туристичну дестинацію 3 метою стимулювання економічного розвитку в регіоні $\epsilon$ передумовою для розвитку діаспорного туризму. У статті описано досвід та сприйняття подорожей на свою історичну батьківщину представниками української діаспори США та Канади, опитування яких проводилось авторами дослідження у 2012-2014 pp. Респонденти, у порівнянні зі середньостатистичними туристами, частіше відвідують сільські місцевості, вони залишаються в Україні на довший термін (в середньому 12-14 днів), витрачають більше грошей, можуть генерувати бізнес-контакти 3 економічно розвинутими країнами, а також сприяти промоції та збереженню української культури як елементу, який єднає їх із предками.

Незважаючи на те, що в Україні відсутнє трактування діаспорного туризму як інструменту регіонального розвитку, а особливо розвитку сільських місцевостей, для цього існує чимало історичних, культурних, економічних та політичних передумов.

Спеціалізовані туристичні оператори, нішею яких є діаспорний туризм, також вказують на потенціал діаспори у відродженні туристичних потоків до України. Натомість органи державної влади не зосереджують своїх зусиль на цьому сегменті, вважаючи більш ефективною політику промоції туризму загалом, без спрямування своїх зусиль на окремі сегменти.

Ключові слова: діаспора, діаспорний туризм, Західна Україна, національна ідентичність, розвиток туризму. 